\title{
Antioxidant Activity and Functional Properties of Polymerized Whey Products by Glycation Process
}

\author{
Liliana Ortega, ${ }^{1}$ Anabel Romero, ${ }^{1}$ Claudia Muro, ${ }^{1}$ and Francisco Riera ${ }^{2}$ \\ ${ }^{1}$ Departamento de Ingeniería Química e Investigación, Instituto Tecnológico de Toluca, Apartado Postal 890, 52149 Metepec, \\ MEX, Mexico \\ ${ }^{2}$ Departamento de Ingeniería Química y Tecnología de Medio Ambiente, Universidad de Oviedo, Oviedo, 33006 Asturias, Spain
}

Correspondence should be addressed to Claudia Muro; cmuro@ittoluca.edu.mx

Received 14 March 2015; Revised 8 June 2015; Accepted 23 June 2015

Academic Editor: Xingxun Liu

Copyright (C) 2015 Liliana Ortega et al. This is an open access article distributed under the Creative Commons Attribution License, which permits unrestricted use, distribution, and reproduction in any medium, provided the original work is properly cited.

\begin{abstract}
The antioxidant properties of sweet and acid whey products were incremented by polymerization of their proteins by glycation of whey protein concentrates (WPC) and their hydrolyzates (WPCH) with ribose and glucose in individual experiments under similar concentration. Heating at $50^{\circ} \mathrm{C}$ during $20 \mathrm{~h}$ maximum and $\mathrm{pH} 7$ and $\mathrm{pH} 9$ were used in all tests. The higher activity was found in WPC glycosylates products with ribose at $\mathrm{pH} 7$ and heating during 10-15 h. In comparable form, antioxidant activity in WPCH was incremented by prior hydrolysis to glycation with $25-45 \%$ of hydrolysis degree. Further functional properties of whey proteins (solubility, emulsion, and foam) were also improved by the polymerization with ribose. The color of polymerized products due to Maillard reactions was associated with antioxidant activity of each compound; however comparative color in glycosylates products with glucose and ribose did not show this effect.
\end{abstract}

\section{Introduction}

Today is known the mediator action of some biopolymers on structure and lipid oxidation of sensitive foods; among them are the functional whey proteins [1-3]. Due to their antioxidative effects (which include chelating of prooxidant transition metals), low molecular weight, easy absorption, high activity, hypoallergenicity, and relatively high stability under different conditions, whey proteins may be utilized in formulations of substitutes of synthetic compounds such as butylated hydroxyanisole (BHA), butylated hydroxytoluene (BHT), and tertbutyl hydroquinone (TBHQ). Mainly proteins as lactoferrin [4], serum albumin [5], and free radical scavenging by amino acid residues such as cysteine and tyrosine $[6,7]$ are described as retardants of the fast deterioration of foods and to prevent the autoxidation of their components.

However, in order to improve their properties and functionality, currently, various researches have been carried out to get better effects of whey products on foods by treatments aimed at modifying chemical structure. Recent studies show that antioxidant capacity can be incremented by enzymatic hydrolysis [8-11], chemical methods such as acetylation, deamination, succinylation, and reductive alkylation, and creating covalent cross-links (polymerization) between food biopolymers and carbohydrates $[12,13]$. In particular, special attention has been provided to the effect exerted by reducing sugars on the structure and protein via Maillard reaction (MR)

Additionally, polymerization or glycation has also a significant impact on protein functionality as gelling, heat stability, emulsifying, and foaming capability. Thus these compounds can exhibit improvement in the antioxidant capacity and functionality when they are added in emulsions $[14,15]$. MR products can also increment the properties of the food such as appearance, flavor, and texture during their processing and storage [16-18]. Furthermore, they also may significantly improve the other biological competences as antimicrobial ability and antihypertensive properties [1921]. However, despite these benefits, the glycation by MR may negatively affect the purpose of modification of whey proteins. Products of MR can act as prooxidants, depending on the states or progress of the reaction. The thermal and $\mathrm{pH}$ 
conditions, nature, and concentration of proteins and sugars contribute to this drastic and contrary effect.

Sugar fragmentation and degradation of amino acids (Strecker degradation) occurring in advanced stages of the reaction may aggravate antioxidant action. In addition, polymerized compounds which in turn produce irreversible or intermediates reactions and the interaction between them, may also affect the antioxidant activity of the products of glycation. Besides training of melanoidins characterized, many of them with typical aroma and flavor [22] are found as product of MR in advanced stages. Therefore, the manipulation of whey proteins properties is an important topic in food industries and more studies are necessary to determine the potential glycation and their influence on their functionality as food additive. Due to the complexity of MR, it is necessary to deepen the study of parameters to these reactions and type of carbohydrate utilized in the glycation.

The aim of this work was to evaluate the antioxidant activity and functional properties of products obtained by combination of enzymatic hydrolysis and glycation process of proteins concentrates from milk bovine whey. Hydrolyzates were obtained by contact with Bacillus subtilis. Nature of the sugar on functionality of products was analyzed by individual experiments with ribose and glucose under controlled conditions of carbohydrate concentration, temperature, and $\mathrm{pH}$.

\section{Materials and Methods}

2.1. Materials. Samples of $2 \mathrm{~L}$ of acid and sweet bovine whey milk were provided by a cheese industry localized in Mexico. The 2,2' azino-bis(3-ethylbenzothiazoline-6-sulfonic acid) (ABTS) and reducing sugars, glucose, ribose, and arabinose were purchased from Sigma Aldrich. Other chemicals agents used were of analytical grade.

2.2. Preparation of Whey Protein Concentrates. Samples of whey of $1 \mathrm{~L}$ were filtered to remove fat and casein particles by vacuum filtration using Whatman filter paper number 40 .

Then, whey was concentrated by ultrafiltration process (UF) to obtain whey proteins concentrates (WPC). In this case was used cross-flow zirconium-titanium ceramic membrane of $15 \mathrm{kDa}$ cut-off and polymeric membrane (hollow fiber) of $6 \mathrm{kDa}$ cut-off (Pall). Tubular housing of tangential flow of membrane was adapted to a peristaltic pump. The transmembrane pressures were adjusted and controlled to 3.0 and 0.3 bar in ceramic and polymeric membrane, respectively. Whey feeding was performed at $25^{\circ} \mathrm{C}$ to both concentration processes. In each UF experiment, two streams were obtained: the retentate (WPC) and permeate (lactose and minerals, mainly).

Diafiltration was performed by addition of five volumes of deionized water to the retentate to maintain a constant volume during UF process [23].

UF was stopped after approximately $18 \mathrm{~h}$ of filtration. Proteins in whey and WPC were determined by Biuret method. The percent yield $(Y)$ of WPC was calculated using

$$
\% Y=\frac{V_{2} C_{2}}{V_{1} C_{1}}(100),
$$

where $C_{2}$ is protein concentration in the retentate after UF; $C_{1}$ is protein concentration in the whey sample; $V_{1}$ is initial volume of whey sample; and $V_{2}$ is final volume in the retentate after UF.

To perform the next experiments, WPC products were chosen according to the highest proteins concentration.

\subsection{Preparation of Hydrolyzed Products from Whey Protein} Concentrates. Hydrolyzed products WPCH were obtained by direct contact of substrates WPC with suspended biomass of Bacillus subtilis in relation $1: 1$. WPC samples were previously adjusted to $\mathrm{pH}$ 7. B. subtilis was previously maintained in the laboratory on nutrient broth agar slants $(5 \mathrm{~g} / \mathrm{L}$ beef extract, $10 \mathrm{~g} / \mathrm{L}$ peptone, $5 \mathrm{~g} / \mathrm{L}$ sodium chloride, $18 \mathrm{~g} / \mathrm{L}$ agar, and $\mathrm{pH} 7-$ 7.4) and stored at $4^{\circ} \mathrm{C}[23]$.

The hydrolysis was performed in a shaking bath (Shel$\mathrm{Lab})$ at $100 \mathrm{rpm}$ and $50^{\circ} \mathrm{C}$. In this experiment, WPC was used as control group; the sample was treated under the same experimental conditions.

Upon completion of the hydrolysis experiment $(24 \mathrm{~h})$, the B. subtilis was inactivated at a temperature of $70^{\circ} \mathrm{C}$ in a water bath for $3 \mathrm{~min}$, then the tubes were centrifuged for 15 minutes at $5000 \mathrm{rpm}$, and the supernatant was diluted with dilution factor of 100 , to determine the protein concentration by Biuret method [23]. Degree of hydrolysis (\%DH) of WPC was determined by measuring the proteins concentration every 2 hours during $12 \mathrm{~h}$ of uninterrupted hydrolysis and was calculated by [23]

$$
\% \mathrm{DH}=\frac{C_{o}-C_{f}}{C_{f}}(100),
$$

where $C_{o}$ is the initial protein concentration in WPC and $C_{f}$ is the protein concentration in supernatant hydrolyzed product for hydrolysis time.

2.4. Preparation of Polymerized Products from Whey by Glycation Process. Polymerized products from whey by glycation process were obtained by the coupling of the samples WPC and WPCH with a carbohydrate (ribose and glucose), according to a method previously developed [24].

Carbohydrate solution was previously prepared by buffer dissolution $\mathrm{pH} 7$ of sodium citrate and buffer dissolution $\mathrm{pH}$ 9 of sodium carbonate, each one with $0.2 \mathrm{~g}$ of carbohydrate.

Samples of WPC and WPCH were placed in direct contact with carbohydrate $(1: 4 \mathrm{v} / \mathrm{v})$ at $\mathrm{pH} 7$ and $\mathrm{pH} 9$, in individual experiments. The mixtures were stirred at room temperature for $1 \mathrm{~h}$ to form uniform dispersion. Afterwards, the mixtures were then incubated at $50^{\circ} \mathrm{C}$ during $20 \mathrm{~h}$.

For the period of glycation process, each mixture was sampled in intervals of time of $5 \mathrm{~h}$ to $20 \mathrm{~h}$. Products were characterized by color change, antioxidant activity, and functional properties.

Sweet and acid whey were used as control group; the samples were only heated under the same experimental conditions.

Glycated products were identified as W, WPC-R, WPC-G, and WPCH-R, WPCH-G for whey, whey concentrates, and 
hydrolyzed product with ribose and glucose in different times of hydrolysis and glycation processes, respectively.

\subsection{Determination of the Properties of Whey Products}

2.5.1. Antioxidant Activity. The antioxidant activity of whey products was assessed by scavenging of the ABTS radical [25].

ABTS•+ radical was previously prepared as follows: $0.0336 \mathrm{~g}$ of ammonium persulfate and $0.0194 \mathrm{~g}$ of ABTS were diluted in $30 \mathrm{~mL}$ of distilled water. This solution was incubated during $16 \mathrm{~h}$ at $25^{\circ} \mathrm{C}$ in the dark. After this time, $40 \mathrm{~mL}$ of ABTS ++ solution was dissolved in $960 \mathrm{~mL}$ of absolute ethanol, reaching an absorbance of $0.7 \pm 0.2$ to $754 \mathrm{~nm}$.

A calibration curve using ascorbic acid $0.002019 \mathrm{M}$ was built as standard substance. Solutions from 0 to $0.8 \mathrm{mM}$ ascorbic acid were prepared in this stage.

Aliquots of $20 \mu \mathrm{L}$ of these solutions were added to $980 \mu \mathrm{L}$ of ABTS solution (absorbance of $0.7 \pm 0.2$ to $754 \mathrm{~nm}$ ). Each mixture was incubated in the dark for $7 \mathrm{~min}$, and the absorbance at $754 \mathrm{~nm}$ was measured for all samples.

The ABTS radical scavenging activity (\%AA) was calculated as inhibition percentage according to

$$
\% \mathrm{AA}=\frac{A_{c}-A_{s}}{A_{c}}(100),
$$

where $A_{c}$ is the absorbance of the control (ABTS solution without samples) and $A_{s}$ is the absorbance of the samples of ascorbic acid.

Antioxidant activity of whey products was analyzed in a similar manner. Briefly, $20 \mu \mathrm{L}$ of each product was mixed with $980 \mu \mathrm{L}$ of the diluted ABTS, the mixture was incubated in the dark for $7 \mathrm{~min}$, and the absorbance at $734 \mathrm{~nm}$ was also measured.

The change in absorbance with the percent inhibition of the radical ABTS•+ was calculated for each sample. The data were reported as antioxidant activity equivalent to ascorbic acid (AAEAA) and \%AA [23].

2.5.2. Functional Properties. The functional properties of whey products were analyzed by measuring their solubility at $\mathrm{pH} 4.5$ and 6.8, emulsions, and foaming capacities.

Solubility was calculated as the total protein concentration in the supernatant of products after centrifugation at $\mathrm{pH}$ 4.6 as a percentage of the initial concentration at $\mathrm{pH} 6.8$ [26].

Whey products $(25 \pm 5 \mathrm{mg})$ were dispersed in $10 \mathrm{~mL}$ of deionized water and the $\mathrm{pH}$ was adjusted with $\mathrm{HCl}(1 \mathrm{~N})$ or $\mathrm{NaOH}(1 \mathrm{~N})$ when necessary. The dispersion was mixed for $30 \mathrm{~min}$ and centrifuged continuously $(x \mathrm{~g} \times 2056)$ for 10 min (Hettich Zentrifugen $32 \mathrm{R}$ ). The amount of protein in the supernatant was determined by the Biuret method; the solubility was expressed as the percentage of protein in the supernatant, the total in the initial products.

Emulsification capacity of whey products and their stability were analyzed using the method developed by Pearce and Kinsella [27]. In this case, $1.5 \mathrm{~mL}$ of corn oil was added to $22.5 \mathrm{mg}$ whey products previously dissolved in $4.5 \mathrm{~mL} 0.01 \mathrm{M}$ phosphate buffer, $\mathrm{pH}$ 7. The mixture was homogenized at $20,000 \mathrm{rpm}$ at room temperature during $1 \mathrm{~min}$.
The stability of products was determined in qualitative form when a breakdown of the emulsion was observed; the volume of added oil was registered and used to calculate the percent \%CEM by

$$
\% \mathrm{CEM}=\frac{V}{V_{1}}(100),
$$

where $V$ is $\mathrm{mL}$ of oil and $V_{1}$ is $\mathrm{mL}$ of whey products.

Regarding foaming capacity (FC) of products, it was determined at $\mathrm{pH}$, adjusting the samples with $\mathrm{NaOH}(0.1 \mathrm{~N})$ at $20^{\circ} \mathrm{C}$.

For the test, $1 \mathrm{~mL}$ of sample was mixed with $72 \mathrm{~mL}$ of distilled water with stirring for $3 \mathrm{~min}$ using a high-speed stirrer of $2000 \mathrm{rpm}$. FC was determined by volume of sample achieved after this time, using

$$
\mathrm{CE}=\frac{V_{f}-V_{i}}{V_{i}}(100),
$$

where $V_{f}$ and $V_{i}$ are the final and the initial volumes of sample, respectively.

The color change of whey products obtained by MR during glycation was also determined. Spectra of 200 to 700 nm using a Perkin Elmer spectrophotometer Lambda 35 were obtained for each sample. The results were shown as identification of redness and yellowness color in the products. Sample whey was used as standard to obtain the spectra.

2.6. Statistical Analysis. Statistica 7.0 software (Statsoft Inc., Tulsa, OK, USA) was utilized to analyze the data obtained from whey characteristics, antioxidant activity, and functional properties on glycation products in experiments with three replicates. Results were compared using ANOVA and Tukey post hoc test $(P<0.05)$.

\section{Results and Discussion}

3.1. Products from Whey Proteins Concentrates. The sweet and acid whey samples showed $\mathrm{pH}$ of 6.5 and 4.5, respectively, values representing the difference between both whey types, which depends on the technological process used to manufacture the cheese.

The average content $(7.89 \pm 0.1$ and $8.73 \pm 0.1 \mathrm{~g} / \mathrm{L})$ indicated that both whey types did not have significant difference in protein content and the values obtained were within those reported by Tovar Jiménez et al. [23] (6-13 g/L). Difference in whey features may be attributed to the milk used and the cheese elaboration.

Concerning UF processes of whey, it was found that performing the UF with polymeric membrane was possible to achieve an excellent yield in the protein concentration among 96-98\% for sweet and acid whey. The products from UF were identified as WPC-1 (from sweet whey and retentate from polymeric membrane); WPC-2 (from acid whey and retentate from polymeric membrane); WPC-3 (from sweet whey and retentate from ceramic membrane); WPC-4 (from acid whey and retentate from ceramic membrane).

Table 1 shows protein composition of WPC products obtained by UF processes with ceramic membrane of $15 \mathrm{kDa}$ 
TABLE 1: Protein concentration $(\mathrm{g} / \mathrm{L})$ in crude whey and WPC products by UF processes.

\begin{tabular}{lccc}
\hline Membrane & & Ceramic & Polymeric \\
\hline Sample type & Whey & WPC & WPC \\
Acid & $8.73 \pm 0.5$ & $5.35 \pm 0.4$ & $8.55 \pm 0.3$ \\
Sweet & $7.89 \pm 0.3$ & $4.58 \pm 0.5$ & $7.41 \pm 0.3$ \\
\hline
\end{tabular}

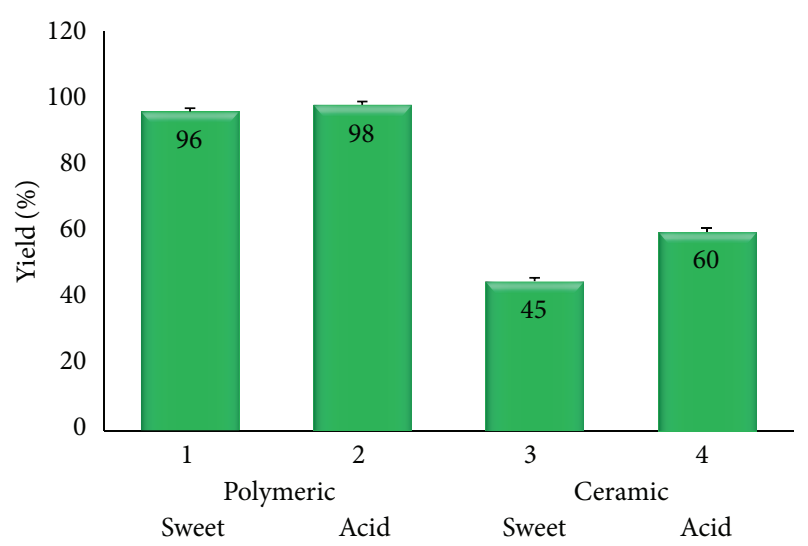

FIGURE 1: Percentage of yield in WPC by UF processes of sweet and acid whey with polymeric and ceramic membrane.

and polymeric membrane of $3 \mathrm{kDa}$, while Figure 1 shows the final percent yield $(Y)$ of each WPC. Difference between the yields in the UF is due to cut-off of membranes. Therefore, it is possible that the proteins of great molecular weight as albumin, Immunoglobulins, and lactoferrin are found intact in the WPC from ceramic membrane, but fewer amounts of $\beta$-lactoglobulin and $\alpha$-lactalbumin are present in the retentates from $15 \mathrm{kDa}$ membrane, since another amount of these proteins is found in their permeate streams.

Under yield result in UF process, in this stage were chosen the products WPC- 1 and WPC-2 (retentates from polymeric membrane) to continue with their hydrolysis.

\subsection{Hydrolyzed Products from Whey Protein Concentrates.} Degree of hydrolysis (\%DH) achieved during $24 \mathrm{~h}$ was $45-$ $60 \%$ from WPC-1 and WPC-2, respectively. Data of hydrolysis process are showed in Figure 2. This test indicated that during $12 \mathrm{~h}$ the changes were observed as more representative in the two types of whey due to enzymatic action from $B$. subtilis. After this period, the $\% \mathrm{DH}$ increased very slowly.

Differences of enzymatic action from B. subtilis have been reported in other researches; however other substrates and enzymatic extracts or purified enzymes from $B$. subtilis have been used in these experiments. For example, maximum values around $70 \%$ of hydrolysis were found on rapeseed meal with enzymatic extract [28] and similar percentage with commercial proteases such as Alcalase on soybean and Subtilisin on whey proteins can be seen in $[29,30]$. Particularly, in [30], it was found that $26 \% \mathrm{DH}$ of whey proteins is obtained after two hours of direct contact with Subtilisin to achieve $70 \%$ in $10 \mathrm{~h}$, which could be compared with \%DH obtained in this work.

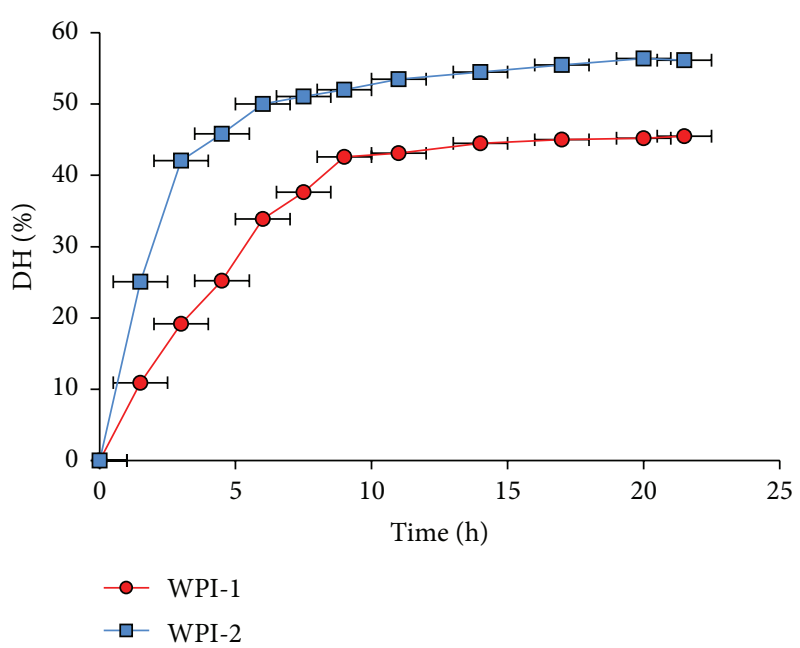

Figure 2: \%DH from WPC-1 and WPC-2 with biomass from $B$. subtilis.

3.3. Polymerized Products from Whey Proteins by Glycation Process. Hundred eighty coded polymerized products were obtained during $20 \mathrm{~h}$. Data are reported by conforming sweet or acid whey produced by only heating (W-1 and W-2); glycation of WPC from each whey type and ribose and galactose (WPC-1, WPC-2, WPC-1-R, WPC-1-G, WPC-2$\mathrm{R}$, and WPC-2-G); and glycation of hydrolyzed products obtained with 25,35 , and $45 \% \mathrm{DH}$ of WPC of sweet whey hydrolysis and 25,45 , and $60 \%$ DH of WPC of acid whey, during 4,8 , and $12 \mathrm{~h}$, respectively (WPCH-1-25-R, WPCH1-35-R, WPCH-1-45-R, WPCH-2-25-R, WPCH-2-45-R, and WPCH-2-60-R), for $\mathrm{pH} 7$ and $\mathrm{pH} 9$ and of the same form to glucose.

Tables 2 to 6 show a summary of the main results on features of some glycosylated product from sweet and acid whey with ribose and glucose. In particular, products with higher antioxidant activity are shown in Figure 3.

Principally, data of Table 2 correspond to glycosylated products from sweet and acid whey by heating of samples. AAEAA values indicated that a significant enhancement $(0.55$ to 0.75 ) was observed in the products by only acid and sweet whey heating for $15-20 \mathrm{~h}$ at $\mathrm{pH} 7$. However no enhancement was observed in samples at $\mathrm{pH} 9$.

In relation to WPC products, a higher AAEAA value was obtained in WPC- $\mathrm{R}$ conjugates (0.56 to 1.02$)$ at $\mathrm{pH} 7$ with heating time, while the increment of AAEAA in WPC-G conjugates was less (0.56 to 0.78$)$ at $\mathrm{pH} 7$ and $\mathrm{pH}$ 9. Data can be observed in Tables 3 and 4 .

Information from WPCH conjugate products corresponding to glycosylated WPC with ribose previously hydrolyzed with biomass from $B$. subtilis is shown in Tables 5 and 6 . AAEAA values of these products indicate that hydrolyzed WPCH can increment their AAEAA value by polymerization with carbohydrates. In general, WPCH conjugates exhibited adequate potency to react with free radicals. $\% \mathrm{DH}$ was sufficient to liberate reactive peptides and produce polymerized products with high AAEAAA values in all experiments. Particularly, products with $25 \%$ DH from WPCacid whey-ribose at pH 7 achieved $1.55-1.85$ of AAEAA and 
TABLE 2: Features of glycosylated product from sweet and acid whey with heating to $50^{\circ} \mathrm{C}, \mathrm{pH} 7$ and $\mathrm{pH} 9$.

\begin{tabular}{|c|c|c|c|c|c|c|c|}
\hline \multirow{2}{*}{ Sample } & \multirow{2}{*}{ Glycosylation time (h) } & \multirow{2}{*}{ Product } & \multicolumn{2}{|c|}{ Antioxidant activity } & \multicolumn{3}{|c|}{ Functional properties } \\
\hline & & & $\%$ AA & AAEAA $(\mathrm{mM} / \mathrm{L})$ & \%Solubility & \%Emulsion & \%Foam \\
\hline \multirow{5}{*}{ Sweet whey at pH 7} & 0 & W7-1 & $25.10 \pm 0.2$ & 0.55 & $80 \pm 0.2$ & $20 \pm 0.1$ & $1.3 \pm 0.2$ \\
\hline & 5 & W7-1-30 & $29.05 \pm 0.2$ & 0.57 & $78 \pm 0.2$ & $22 \pm 0.1$ & $1.3 \pm 0.2$ \\
\hline & 10 & W7-1-60 & $32.43 \pm 0.1$ & 0.68 & $78 \pm 0.2$ & $21 \pm 0.1$ & $1.3 \pm 0.1$ \\
\hline & 15 & W7-1-120 & $34.67 \pm 0.2$ & 0.70 & $75 \pm 0.2$ & $22 \pm 0.1$ & $1.2 \pm 0.2$ \\
\hline & 20 & W7-1-180 & $35.31 \pm 0.2$ & 0.75 & $75 \pm 0.2$ & $20 \pm 0.1$ & $1.1 \pm 0.1$ \\
\hline \multirow{5}{*}{ Sweet whey at pH 9} & 0 & W9-1 & $19.65 \pm 0.5$ & 0.41 & $75 \pm 0.2$ & $20 \pm 0.1$ & $1.0 \pm 0.1$ \\
\hline & 5 & W9-1-30 & $20.33 \pm 0.2$ & 0.42 & $71 \pm 0.2$ & $19 \pm 0.2$ & $1.1 \pm 0.1$ \\
\hline & 10 & W9-1-60 & $20.99 \pm 0.3$ & 0.42 & $74 \pm 0.2$ & $20 \pm 0.2$ & $1.1 \pm 0.1$ \\
\hline & 15 & W9-1-120 & $21.85 \pm 0.3$ & 0.43 & $75 \pm 0.2$ & $19 \pm 0.2$ & $1.1 \pm 0.2$ \\
\hline & 20 & W9-1-180 & $22.59 \pm 0.3$ & 0.45 & $75 \pm 0.2$ & $19 \pm 0.1$ & $1.2 \pm 0.1$ \\
\hline \multirow{5}{*}{ Acid whey at pH 7} & 0 & W7-2 & $42.21 \pm 0.4$ & 0.62 & $70 \pm 0.1$ & $17 \pm 0.1$ & $0.8 \pm 0.1$ \\
\hline & 5 & W7-2-30 & $44.76 \pm 0.5$ & 0.65 & $68 \pm 0.2$ & $17 \pm 0.1$ & $0.7 \pm 0.1$ \\
\hline & 10 & W7-2-60 & $48.32 \pm 0.5$ & 0.73 & $65 \pm 0.1$ & $15 \pm 0.1$ & $0.5 \pm 0.1$ \\
\hline & 15 & W7-2-120 & $49.05 \pm 0.5$ & 0.75 & $65 \pm 0.1$ & $14 \pm 0.2$ & $0.5 \pm 0.2$ \\
\hline & 20 & W7-2-180 & $49.88 \pm 0.3$ & 0.76 & $60 \pm 0.1$ & $13 \pm 0.1$ & $0.5 \pm 0.2$ \\
\hline \multirow{5}{*}{ Acid whey at pH 9} & 0 & W9-2 & $21.22 \pm 0.1$ & 0.42 & $70 \pm 0.1$ & $15 \pm 0.1$ & $0.8 \pm 0.2$ \\
\hline & 5 & W9-2-30 & $22.54 \pm 0.1$ & 0.43 & $72 \pm 0.1$ & $17 \pm 0.1$ & $0.8 \pm 0.1$ \\
\hline & 10 & W9-2-60 & $22.78 \pm 0.2$ & 0.43 & $78 \pm 0.2$ & $18 \pm 0.2$ & $0.8 \pm 0.1$ \\
\hline & 15 & W9-2-120 & $23.94 \pm 0.2$ & 0.44 & $78 \pm 0.2$ & $18 \pm 0.2$ & $0.9 \pm 0.1$ \\
\hline & 20 & W9-2-180 & $24.05 \pm 0.2$ & 0.44 & $75 \pm 0.2$ & $17 \pm 0.1$ & $0.8 \pm 0.1$ \\
\hline
\end{tabular}

TABLE 3: Features of glycosylated product from WPC of sweet and acid whey with ribose, heating to $50^{\circ} \mathrm{C}, \mathrm{pH} 7$ and $\mathrm{pH} 9$.

\begin{tabular}{|c|c|c|c|c|c|c|c|}
\hline \multirow{2}{*}{ Sample } & \multirow{2}{*}{ Glycosylation time (h) } & \multirow{2}{*}{ Product } & \multicolumn{2}{|c|}{ Antioxidant activity } & \multicolumn{3}{|c|}{ Functional properties } \\
\hline & & & $\% \mathrm{AA}$ & $\operatorname{AAEAA}(\mathrm{mM} / \mathrm{L})$ & \%Solubility & \%Emulsion & \%Foam \\
\hline \multirow{5}{*}{$\begin{array}{l}\text { WPC } \\
\text { sweet whey with ribose at pH } 7\end{array}$} & 0 & WPC7-1-R & $51 \pm 0.6$ & 0.56 & $90 \pm 0.2$ & $80 \pm 0.2$ & $25 \pm 0.2$ \\
\hline & 5 & WPC7-1-30-R & $53 \pm 0.5$ & 0.58 & $88 \pm 0.2$ & $80 \pm 0.2$ & $25 \pm 0.2$ \\
\hline & 10 & WPC7-1-60-R & $55 \pm 0.5$ & 0.65 & $88 \pm 0.2$ & $78 \pm 0.1$ & $26 \pm 0.2$ \\
\hline & 15 & WPC7-1-120-R & $60 \pm 0.2$ & 0.70 & $85 \pm 0.1$ & $78 \pm 0.1$ & $26 \pm 0.2$ \\
\hline & 20 & WPC7-1-180-R & $77 \pm 0.2$ & 0.75 & $85 \pm 0.1$ & $75 \pm 0.1$ & $27 \pm 0.2$ \\
\hline \multirow{5}{*}{$\begin{array}{l}\text { WPC } \\
\text { sweet whey with ribose at } \mathrm{pH} 9\end{array}$} & 0 & WPC9-1-R & $40 \pm 0.3$ & 0.50 & $85 \pm 0.2$ & $80 \pm 0.2$ & $26 \pm 0.1$ \\
\hline & 5 & WPC9-1-30-R & $41 \pm 0.5$ & 0.54 & $80 \pm 0.2$ & $78 \pm 0.3$ & $25 \pm 0.1$ \\
\hline & 10 & WPC9-1-60-R & $45 \pm 0.5$ & 0.58 & $75 \pm 0.2$ & $75 \pm 0.2$ & $23 \pm 0.1$ \\
\hline & 15 & WPC9-1-120-R & $54 \pm 0.5$ & 0.65 & $78 \pm 0.2$ & $78 \pm 0.1$ & $25 \pm 0.2$ \\
\hline & 20 & WPC9-1-180-R & $60 \pm 0.5$ & 0.76 & $78 \pm 0.2$ & $79 \pm 0.1$ & $26 \pm 0.1$ \\
\hline \multirow{5}{*}{$\begin{array}{l}\text { WPC } \\
\text { acid whey with ribose at } \mathrm{pH} 7\end{array}$} & 0 & WPC7-2-R & $55 \pm 0.5$ & 0.56 & $89 \pm 0.2$ & $82 \pm 0.1$ & $30 \pm 0.1$ \\
\hline & 5 & WPC7-2-30-R & $59 \pm 0.5$ & 0.62 & $88 \pm 0.1$ & $80 \pm 0.2$ & $30 \pm 0.2$ \\
\hline & 10 & WPC7-2-60-R & $70 \pm 0.3$ & 0.70 & $85 \pm 0.1$ & $78 \pm 0.3$ & $27 \pm 0.2$ \\
\hline & 15 & WPC7-2-120-R & $80 \pm 0.5$ & 1.02 & $85 \pm 0.1$ & $80 \pm 0.1$ & $25 \pm 0.3$ \\
\hline & 20 & WPC7-2-180-R & $77 \pm 0.5$ & 0.92 & $83 \pm 0.1$ & $78 \pm 0.1$ & $23 \pm 0.3$ \\
\hline \multirow{5}{*}{$\begin{array}{l}\text { WPC } \\
\text { acid whey with ribose at } \mathrm{pH} 9\end{array}$} & 0 & WPC9-2-R & $40 \pm 0.1$ & 0.50 & $75 \pm 0.1$ & $65 \pm 0.1$ & $\overline{19 \pm 0.2}$ \\
\hline & 5 & WPC9-2-30-R & $45 \pm 0.5$ & 0.53 & $78 \pm 0.1$ & $70 \pm 0.3$ & $20 \pm 0.3$ \\
\hline & 10 & WPC9-2-60-R & $45 \pm 0.5$ & 0.55 & $79 \pm 0.1$ & $70 \pm 0.1$ & $20 \pm 0.2$ \\
\hline & 15 & WPC9-2-120-R & $48 \pm 0.1$ & 0.55 & $80 \pm 0.2$ & $70 \pm 0.1$ & $22 \pm 0.3$ \\
\hline & 20 & WPC9-2-180-R & $46 \pm 0.3$ & 0.50 & $75 \pm 0.2$ & $65 \pm 0.1$ & $20 \pm 0.3$ \\
\hline
\end{tabular}


TABLE 4: Features of glycosylated product from WPC of sweet whey with glucose and heating to $50^{\circ} \mathrm{C}, \mathrm{pH} 7$ and $\mathrm{pH} 9$.

\begin{tabular}{|c|c|c|c|c|c|c|c|}
\hline \multirow{2}{*}{ Sample } & \multirow{2}{*}{ Glycosylation time (h) } & \multirow{2}{*}{ Product } & \multicolumn{2}{|c|}{ Antioxidant activity } & \multicolumn{3}{|c|}{ Functional properties } \\
\hline & & & $\% \mathrm{AA}$ & AAEAA (mM/L) & \%Solubility & \%Emulsion & \%Foam \\
\hline \multirow{5}{*}{$\begin{array}{l}\text { WPC } \\
\text { sweet whey with glucose at } \mathrm{pH} 7\end{array}$} & 0 & WPC7-1-G & $50 \pm 0.5$ & 0.30 & $70 \pm 0.1$ & $62 \pm 0.1$ & $25 \pm 0.1$ \\
\hline & 5 & WPC7-1-30-G & $58 \pm 0.6$ & 0.42 & $75 \pm 0.1$ & $66 \pm 0.2$ & $28 \pm 0.1$ \\
\hline & 10 & WPC7-1-60-G & $59 \pm 0.5$ & 0.42 & $75 \pm 0.1$ & $65 \pm 0.2$ & $30 \pm 0.1$ \\
\hline & 15 & WPC7-1-120-G & $60 \pm 0.7$ & 0.52 & $77 \pm 0.2$ & $65 \pm 0.1$ & $30 \pm 0.2$ \\
\hline & 20 & WPC7-1-180-G & $62 \pm 0.5$ & 0.55 & $75 \pm 0.3$ & $61 \pm 0.1$ & $25 \pm 0.1$ \\
\hline \multirow{5}{*}{$\begin{array}{l}\text { WPC } \\
\text { sweet whey with glucose at } \mathrm{pH} 9\end{array}$} & 0 & WPC9-1-G & $39 \pm 0.5$ & 0.20 & $71 \pm 0.2$ & $60 \pm 0.1$ & $20 \pm 0.3$ \\
\hline & 5 & WPC9-1-30-G & $40 \pm 0.3$ & 0.19 & $70 \pm 0.2$ & $62 \pm 0.2$ & $22 \pm 0.3$ \\
\hline & 10 & WPC9-1-60-G & $45 \pm 0.5$ & 0.23 & $70 \pm 0.1$ & $65 \pm 0.2$ & $22 \pm 0.1$ \\
\hline & 15 & WPC9-1-120-G & $46 \pm 0.5$ & 0.20 & $75 \pm 0.2$ & $66 \pm 0.3$ & $25 \pm 0.1$ \\
\hline & 20 & WPC9-1-180-G & $46 \pm 0.5$ & 0.28 & $78 \pm 0.2$ & $67 \pm 0.1$ & $25 \pm 0.2$ \\
\hline \multirow{5}{*}{$\begin{array}{l}\text { WPC } \\
\text { acid whey with glucose at } \mathrm{pH} 7\end{array}$} & 0 & WPC7-2-G & $49 \pm 0.5$ & 0.30 & $80 \pm 0.1$ & $66 \pm 0.1$ & $30 \pm 0.2$ \\
\hline & 5 & WPC7-2-30-G & $50 \pm 0.6$ & 0.30 & $85 \pm 0.1$ & $69 \pm 0.1$ & $32 \pm 0.2$ \\
\hline & 10 & WPC7-2-60-G & $52 \pm 0.6$ & 0.30 & $86 \pm 0.1$ & $69 \pm 0.1$ & $35 \pm 0.1$ \\
\hline & 15 & WPC7-2-120-G & $55 \pm 0.3$ & 0.35 & $86 \pm 0.1$ & $70 \pm 0.1$ & $36 \pm 0.1$ \\
\hline & 20 & WPC7-2-180-G & $55 \pm 0.3$ & 0.33 & $81 \pm 0.2$ & $71 \pm 0.1$ & $33 \pm 0.1$ \\
\hline \multirow{5}{*}{$\begin{array}{l}\text { WPC } \\
\text { acid whey with glucose at } \mathrm{pH} 9\end{array}$} & 0 & WPC9-2-G & $55 \pm 0.3$ & 0.56 & $76 \pm 0.1$ & $65 \pm 0.2$ & $28 \pm 0.1$ \\
\hline & 5 & WPC9-2-30-G & $58 \pm 0.3$ & 0.68 & $78 \pm 0.1$ & $65 \pm 0.1$ & $25 \pm 0.1$ \\
\hline & 10 & WPC9-2-60-G & $69 \pm 0.3$ & 0.68 & $80 \pm 0.2$ & $69 \pm 0.3$ & $28 \pm 0.2$ \\
\hline & 15 & WPC9-2-120-R & $78 \pm 0.3$ & 0.78 & $75 \pm 0.2$ & $65 \pm 0.3$ & $25 \pm 0.1$ \\
\hline & 20 & WPC9-2-180-R & $75 \pm 0.3$ & 0.75 & $73 \pm 0.2$ & $65 \pm 0.1$ & $20 \pm 0.1$ \\
\hline
\end{tabular}

products with $45 \% \mathrm{DH}$ at $\mathrm{pH} 9$ achieved only 1.1 of AAEAA whereas conjugate products by glycation of hydrolyzed with glucose showed always a lower increase in AAEAA.

In terms of reactants nature, it is understandable that WCPH products were more reactive than WPC; this is due to presence of free amino acids. However, it was found that major contributors to the radical scavenging capacity were primarily composed of WCPH although other authors noted that either the intermediates or the final brown polymer can function as hydrogen donors and that sugar caramelization can also contribute to the antiradical activity [31].

The most reactive peptides are the $-\mathrm{NH}_{2}$ groups of lysine as well as the group $-\mathrm{NH}_{2}$ located at the amino terminus. Therefore, a higher content of residues lysine could lead to a higher degree of protein glycation. The imidazole group of histidine, the indole group of tryptophan, and the guanidino group of arginine residues are also likely to react with reducing sugars, but this possibility is lesser than amino groups [32].

On the other hand, different coloration in conjugates products was also observed during the heating period for each carbohydrate. However, comparative experiments showed that glycosylated products with glucose developed an intense yellow color and characteristic odor, after $15 \mathrm{~h}$ of heating, decreasing at $\mathrm{pH}$ 9, whereas glycosylated products with ribose acquired a faint brownish yellow in similar period.

Thus, it is possible that ribose present as more reactive than the glucose during the different stages of MR, joining

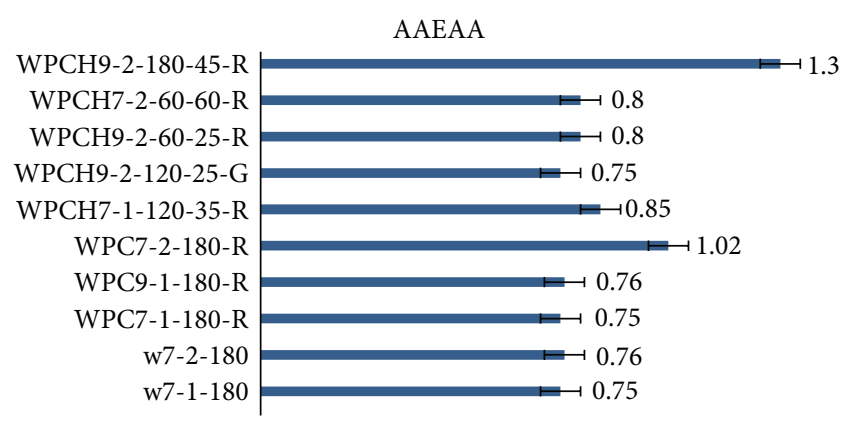

FIGURE 3: AAEAA of representative glycosylated products from whey milk in individual experiments with ribose and glucose at $50^{\circ} \mathrm{C}$ and variations of $\mathrm{pH} 7$ and $\mathrm{pH} 9$.

the products substantially to ribose molecules; this reactive property could be associated with antioxidant power of whey products.

Recent researches have shown that the antioxidant properties of the proteins are enhanced by their conjugation particularly with glucose. Conjugate products from ovalbuminsaccharides [33], whey protein isolate (WPI) [34], and specific conjugates $\alpha$-lactalbumin-glucose [35] showed an increment in their antioxidant activity when the proteins were polymerized with glucose more greatly. These results were highly consistent with the browning intensity of products. Authors found that particularly WPI-conjugates with glucose after 7 days of dry heating at $60^{\circ} \mathrm{C}$ showed an increase in 
TABLE 5: Features of glycosylated product from hydrolyzates from WPC of sweet whey with ribose heating to $50^{\circ} \mathrm{C}, \mathrm{pH} 7$ and $\mathrm{pH} 9$.

\begin{tabular}{|c|c|c|c|c|c|c|c|}
\hline \multirow{2}{*}{ Sample } & \multirow{2}{*}{ Glycosylation time (h) } & \multirow{2}{*}{ Product } & \multicolumn{2}{|c|}{ Antioxidant activity } & \multicolumn{3}{|c|}{ Functional properties } \\
\hline & & & $\% \mathrm{AA}$ & $\operatorname{AAEAA}(\mathrm{mM} / \mathrm{L})$ & \%Solubility & \%Emulsion & \%Foam \\
\hline \multirow{5}{*}{$\begin{array}{l}\text { Hydrolyzate }(25 \% \mathrm{HD}) \text { from } \\
\text { WPC of sweet whey with } \\
\text { ribose at pH } 7\end{array}$} & 0 & WPCH7-1-25-R & $60 \pm 0.7$ & 0.54 & $90 \pm 0.1$ & $80 \pm 0.1$ & $10 \pm 0.1$ \\
\hline & 5 & WPCH7-1-30-25-R & $65 \pm 0.5$ & 0.55 & $90 \pm 0.1$ & $78 \pm 0.1$ & $15 \pm 0.1$ \\
\hline & 10 & WPCH7-1-60-25-R & $68 \pm 0.7$ & 0.55 & $90 \pm 0.2$ & $75 \pm 0.1$ & $15 \pm 0.1$ \\
\hline & 15 & WPCH7-1-120-25-R & $70 \pm 0.8$ & 0.58 & $89 \pm 0.2$ & $75 \pm 0.2$ & $15 \pm 0.2$ \\
\hline & 20 & WPCH7-1-180-25-R & $65 \pm 0.6$ & 0.49 & $85 \pm 0.1$ & $70 \pm 0.2$ & $10 \pm 0.2$ \\
\hline \multirow{5}{*}{$\begin{array}{l}\text { Hydrolyzate }(35 \% \mathrm{HD}) \text { from } \\
\text { WPC of sweet whey with } \\
\text { ribose at pH } 7\end{array}$} & 0 & WPCH7-1-35-R & $75 \pm 0.5$ & 0.68 & $90 \pm 0.1$ & $79 \pm 0.1$ & $20 \pm 0.1$ \\
\hline & 5 & WPCH7-1-30-35-R & $75 \pm 0.6$ & 0.70 & $90 \pm 0.1$ & $80 \pm 0.1$ & $22 \pm 0.1$ \\
\hline & 10 & WPCH7-1-60-35-R & $89 \pm 0.8$ & 1.85 & $85 \pm 0.2$ & $78 \pm 0.2$ & $25 \pm 0.1$ \\
\hline & 15 & WPCH7-1-120-35-R & $85 \pm 0.5$ & 0.95 & $85 \pm 0.3$ & $75 \pm 0.2$ & $20 \pm 0.1$ \\
\hline & 20 & WPCH7-1-180-35-R & $75 \pm 0.8$ & 0.71 & $82 \pm 0.1$ & $70 \pm 0.1$ & $20 \pm 0.2$ \\
\hline \multirow{5}{*}{$\begin{array}{l}\text { Hydrolyzate }(45 \% \mathrm{HD}) \text { from } \\
\text { WPC of sweet whey with } \\
\text { ribose at pH7 }\end{array}$} & 0 & WPCH7-1-45-R & $64 \pm 0.5$ & 0.59 & $89 \pm 0.1$ & $76 \pm 0.2$ & $22 \pm 0.2$ \\
\hline & 5 & WPCH7-1-30-45-R & $65 \pm 0.5$ & 0.55 & $85 \pm 0.2$ & $77 \pm 0.2$ & $20 \pm 0.2$ \\
\hline & 10 & WPCH7-1-60-45-R & $63 \pm 0.7$ & 0.50 & $80 \pm 0.1$ & $75 \pm 0.1$ & $15 \pm 0.1$ \\
\hline & 15 & WPCH7-1-120-45-R & $50 \pm 0.8$ & 0.45 & $78 \pm 0.1$ & $70 \pm 0.2$ & $15 \pm 0.3$ \\
\hline & 20 & WPCH7-1-180-45-R & $40 \pm 0.5$ & 0.30 & $75 \pm 0.1$ & $66 \pm 0.1$ & $15 \pm 0.3$ \\
\hline \multirow{5}{*}{$\begin{array}{l}\text { Hydrolyzate }(25 \% \mathrm{HD}) \text { from } \\
\text { WPC of sweet whey with } \\
\text { ribose at pH } 9\end{array}$} & 0 & WPCH9-1-25-R & $49 \pm 0.4$ & 0.28 & $80 \pm 0.1$ & $69 \pm 0.1$ & $22 \pm 0.1$ \\
\hline & 5 & WPCH9-1-30-25-R & $50 \pm 0.8$ & 0.30 & $85 \pm 0.1$ & $75 \pm 0.1$ & $25 \pm 0.1$ \\
\hline & 10 & WPCH9-1-60-25-R & $52 \pm 0.6$ & 0.35 & $88 \pm 0.2$ & $79 \pm 0.2$ & $25 \pm 0.3$ \\
\hline & 15 & WPCH9-1-120-25-R & $53 \pm 0.8$ & 0.35 & $90 \pm 0.2$ & $80 \pm 0.2$ & $29 \pm 0.1$ \\
\hline & 20 & WPCH9-1-180-25-R & $55 \pm 0.3$ & 0.4 & $90 \pm 0.2$ & $85 \pm 0.1$ & $30 \pm 0.1$ \\
\hline \multirow{5}{*}{$\begin{array}{l}\text { Hydrolyzate }(35 \% \mathrm{HD}) \text { from } \\
\text { WPC of sweet whey with } \\
\text { ribose at pH } 9\end{array}$} & 0 & WPCH9-1-35-R & $50 \pm 0.5$ & 0.55 & $90 \pm 0.1$ & $88 \pm 0.1$ & $33 \pm 0.1$ \\
\hline & 5 & WPCH9-1-30-35-R & $56 \pm 0.5$ & 0.60 & $87 \pm 0.1$ & $89 \pm 0.1$ & $30 \pm 0.2$ \\
\hline & 10 & WPCH9-1-60-35-R & $58 \pm 0.8$ & 0.6 & $88 \pm 0.2$ & $78 \pm 0.2$ & $29 \pm 0.2$ \\
\hline & 15 & WPCH9-1-120-35-R & $55 \pm 0.7$ & 0.53 & $85 \pm 0.2$ & $75 \pm 0.2$ & $25 \pm 0.2$ \\
\hline & 20 & WPCH9-1-180-35-R & $50 \pm 0.5$ & 0.45 & $88 \pm 0.1$ & $80 \pm 0.1$ & $28 \pm 0.2$ \\
\hline \multirow{5}{*}{$\begin{array}{l}\text { Hydrolyzate }(45 \% \mathrm{HD}) \text { from } \\
\text { WPC of sweet whey with } \\
\text { ribose at pH } 9\end{array}$} & 0 & WPCH9-1-45-R & $50 \pm 0.5$ & 0.43 & $89 \pm 0.1$ & $78 \pm 0.1$ & $28 \pm 0.1$ \\
\hline & 5 & WPCH9-1-30-45-R & $48 \pm 0.8$ & 0.35 & $85 \pm 0.1$ & $75 \pm 0.1$ & $25 \pm 0.1$ \\
\hline & 10 & WPCH9-1-60-45-R & $45 \pm 0.8$ & 0.30 & $80 \pm 0.2$ & $73 \pm 0.1$ & $20 \pm 0.2$ \\
\hline & 15 & WPCH9-1-120-45-R & $44 \pm 0.5$ & 0.25 & $80 \pm 0.1$ & $73 \pm 0.1$ & $18 \pm 0.2$ \\
\hline & 20 & WPCH9-1-180-45-R & $40 \pm 0.5$ & 0.20 & $75 \pm 0.1$ & $70 \pm 0.2$ & $15 \pm 0.2$ \\
\hline
\end{tabular}

antioxidant activity and an increase in the color. It was seen in UV-vis absorption and fluorescence intensity. Additionally comparative data on WPI alone indicated that the conjugates exhibited a better thermal stability.

Similar results were found in the present research; however here it is shown that conjugates-ribose enhances antioxidant action than glucose. Difference of antioxidant action can also be associated with the presence of complex mix of compounds developed during glycation of whey products. Glucose could play an important role in the reduction of antioxidant activity. Particularly hydroxyl groups could inhibit this power $[36,37]$.

Carbohydrate type and $\mathrm{pH}$ could explain these results. However, reactivity of carbohydrate in glycation process has not been described still in clear form. According to [37], it has been shown that reactivity decreases with the molecular weight of carbohydrate, which would explain that crosslinking and aggregation protein with ribose is incremented in comparison with the glucose and this behavior could be associated with the increment of antioxidant activity of conjugate whey products-ribose. Reactivity of different sugars is also given by the availability of its carbonyl group; for example, glucose presents at least two closed forms (cyclic anomers) in which the carbonyl group has disappeared. Thus a correlation between the reaction rate of glycation and the proportion of the open form of each sugar is also found in these data.

Influence of $\mathrm{pH}$ in $\mathrm{MR}$ reaction during glycation process may furthermore be observed on antioxidant action of whey products; at basic $\mathrm{pH}$, generally, the polymerization rate increases. However the results cannot be described thus radically.

In an early stage, MR generates Amadori products (glycosylamines $\mathrm{N}$-substituted by sugar-amine condensation) which are present due to reactions between amine groups of proteins and carbonyl groups within the reducing sugar, while intermediate stage and advanced stage are characterized by formation of reactive intermediates such as sugar-derived dicarbonyl compounds as 1-amino-2-deoxy2-ketoses (e.g., methylglyoxal, 3-deoxyosones, or glyoxal) 
TABLE 6: Features of glycosylated product from hydrolyzates from WPC of acid whey with ribose, heating to $50^{\circ} \mathrm{C}, \mathrm{pH} 7$ and $\mathrm{pH} 9$.

\begin{tabular}{|c|c|c|c|c|c|c|c|}
\hline \multirow{2}{*}{ Sample } & \multirow{2}{*}{ Glycosylation time (h) } & \multirow{2}{*}{ Product } & \multicolumn{2}{|c|}{ Antioxidant activity } & \multicolumn{3}{|c|}{ Functional properties } \\
\hline & & & $\% \mathrm{AA}$ & AAEAA (mM/L) & \%Solubility & \%Emulsion & \%Foam \\
\hline \multirow{5}{*}{$\begin{array}{l}\text { Hydrolyzate }(25 \% \mathrm{HD}) \text { from } \\
\text { WPC of acid whey with ribose } \\
\text { at } \mathrm{pH} 7\end{array}$} & 0 & WPCH7-2-25-R & $60 \pm 0.5$ & 0.60 & $88 \pm 0.3$ & $80 \pm 0.1$ & $30 \pm 0.2$ \\
\hline & 5 & WPCH7-2-30-25-R & $65 \pm 0.6$ & 0.58 & $90 \pm 0.2$ & $80 \pm 0.2$ & $35 \pm 0.2$ \\
\hline & 10 & WPCH7-2-60-25-R & $68 \pm 0.5$ & 0.60 & $90 \pm 0.1$ & $80 \pm 0.2$ & $37 \pm 0.2$ \\
\hline & 15 & WPC7-2-120-25-R & $67 \pm 0.5$ & 0.63 & $85 \pm 0.1$ & $78 \pm 0.2$ & $35 \pm 0.2$ \\
\hline & 20 & WPC7-2-180-25-R & $65 \pm 0.5$ & 0.62 & $85 \pm 0.1$ & $79 \pm 0.2$ & $32 \pm 0.2$ \\
\hline \multirow{5}{*}{$\begin{array}{l}\text { Hydrolyzate }(45 \% \mathrm{HD}) \text { from } \\
\text { WPC of acid whey with ribose } \\
\text { at } \mathrm{pH} 7\end{array}$} & 0 & WPCH7-2-45-R & $70 \pm 0.5$ & 0.61 & $90 \pm 0.1$ & $77 \pm 0.2$ & $30 \pm 0.2$ \\
\hline & 5 & WPCH7-2-30-45-R & $80 \pm 0.4$ & 0.75 & $85 \pm 0.3$ & $75 \pm 0.1$ & $28 \pm 0.3$ \\
\hline & 10 & WPCH7-2-60-45-R & $86 \pm 0.6$ & 0.85 & $85 \pm 0.2$ & $77 \pm 0.1$ & $30 \pm 0.2$ \\
\hline & 15 & WPCH7-2-120-45-R & $87 \pm 0.5$ & 1.55 & $84 \pm 0.3$ & $75 \pm 0.1$ & $25 \pm 0.2$ \\
\hline & 20 & WPCH7-2-180-45-R & $85 \pm 0.6$ & 0.90 & $87 \pm 0.2$ & $73 \pm 0.1$ & $25 \pm 0.2$ \\
\hline \multirow{5}{*}{$\begin{array}{l}\text { Hydrolyzate }(60 \% \mathrm{HD}) \text { from } \\
\text { WPC of acid whey with ribose } \\
\text { at } \mathrm{pH} 7\end{array}$} & 0 & WPCH7-2-60-R & $83 \pm 0.5$ & 0.78 & $90 \pm 0.2$ & $75 \pm 0.2$ & $30 \pm 0.2$ \\
\hline & 5 & WPCH7-2-30-60-R & $85 \pm 0.6$ & 0.80 & $90 \pm 0.1$ & $77 \pm 0.2$ & $30 \pm 0.1$ \\
\hline & 10 & WPCH7-2-60-60-R & $88 \pm 0.5$ & 0.80 & $90 \pm 0.2$ & $80 \pm 0.2$ & $30 \pm 0.1$ \\
\hline & 15 & WPCH7-2-120-60-R & $80 \pm 0.4$ & 0.75 & $85 \pm 0.2$ & $78 \pm 0.1$ & $25 \pm 0.2$ \\
\hline & 20 & WPCH7-2-180-60-R & $80 \pm 0.7$ & 0.70 & $80 \pm 0.1$ & $75 \pm 0.1$ & $20 \pm 0.2$ \\
\hline \multirow{5}{*}{$\begin{array}{l}\text { Hydrolyzate }(25 \% \mathrm{HD}) \text { from } \\
\text { WPC of acid whey with ribose } \\
\text { at pH } 9\end{array}$} & 0 & WPCH9-2-25-R & $85 \pm 0.7$ & 0.75 & $90 \pm 0.2$ & $79 \pm 0.1$ & $30 \pm 0.1$ \\
\hline & 5 & WPCH9-2-30-25-R & $88 \pm 0.5$ & 0.80 & $90 \pm 0.1$ & $80 \pm 0.1$ & $30 \pm 0.1$ \\
\hline & 10 & WPCH9-2-60-25-R & $90 \pm 0.5$ & 1.38 & $86 \pm 0.2$ & $78 \pm 0.1$ & $28 \pm 0.2$ \\
\hline & 15 & WPCH9-2-120-25-R & $89 \pm 0.5$ & 0.78 & $85 \pm 0.2$ & $75 \pm 0.1$ & $25 \pm 0.2$ \\
\hline & 20 & WPCH9-2-180-25-R & $85 \pm 0.6$ & 0.75 & $82 \pm 0.1$ & $73 \pm 0.2$ & $25 \pm 0.2$ \\
\hline \multirow{5}{*}{$\begin{array}{l}\text { Hydrolyzate ( } 45 \% \text { HD) from } \\
\text { WPC of acid whey with ribose } \\
\text { at pH } 9\end{array}$} & 0 & WPCH9-2-45-R & $85 \pm 0.5$ & 0.70 & $90 \pm 0.1$ & $75 \pm 0.1$ & $30 \pm 0.1$ \\
\hline & 5 & WPCH9-2-30-45-R & $88 \pm 0.5$ & 0.79 & $85 \pm 0.2$ & $80 \pm 0.1$ & $30 \pm 0.1$ \\
\hline & 10 & WPCH9-2-60-45-R & $90 \pm 0.4$ & 0.80 & $83 \pm 0.2$ & $80 \pm 0.3$ & $30 \pm 0.3$ \\
\hline & 15 & WPCH9-2-120-45-R & $91 \pm 0.5$ & 1.10 & $80 \pm 0.1$ & $80 \pm 0.1$ & $30 \pm 0.3$ \\
\hline & 20 & WPCH9-2-180-45-R & $95 \pm 0.3$ & 1.30 & $78 \pm 0.1$ & $80 \pm 0.2$ & $25 \pm 0.3$ \\
\hline \multirow{5}{*}{$\begin{array}{l}\text { Hydrolyzate }(60 \% \mathrm{HD}) \text { from } \\
\text { WPC of acid whey with ribose } \\
\text { at } \mathrm{pH} 9\end{array}$} & 0 & WPCH9-2-60-R & $80 \pm 0.5$ & 0.75 & $80 \pm 0.2$ & $75 \pm 0.1$ & $20 \pm 0.2$ \\
\hline & 5 & WPCH9-2-30-60-R & $75 \pm 0.5$ & 0.73 & $75 \pm 0.2$ & $70 \pm 0.2$ & $20 \pm 0.1$ \\
\hline & 10 & WPCH9-2-60-60-R & $76 \pm 0.3$ & 0.70 & $72 \pm 0.2$ & $70 \pm 0.2$ & $19 \pm 0.1$ \\
\hline & 15 & WPCH9-2-120-60-R & $75 \pm 0.4$ & 0.67 & $70 \pm 0.2$ & $65 \pm 0.1$ & $17 \pm 0.1$ \\
\hline & 20 & WPCH9-2-180-60-R & $70 \pm 0.5$ & 0.65 & $70 \pm 0.2$ & $65 \pm 0.1$ & $15 \pm 0.1$ \\
\hline
\end{tabular}

which are produced with time, resulting in the formation of polymerized compounds that may be interfering substances affecting the antioxidant activity. In addition, alkaline and/or heat treatment of proteins may be associated with the production of several types of cross-linked amino acids such as dehydroalanine, lysinoalanine, and histidinoalanine, which may affect also antioxidant activity and the nutritional value of the treated whey proteins [37]. Dehydration of sugars occurs by two routes. Under acidic conditions are formed furfurals and at alkaline conditions are formed the reductone. The enolization of the $\mathrm{C}_{2}$ and $\mathrm{C}_{3}$ carbons and removal of the amino group in position 1 give rise to the formation of 2,3dicarbonyl compounds (via 2,3-E), which causes further fragmentation of low molecular weight compounds as ketoaldehydes, reductone, and a-dicarbonyl compounds, while, at acidic $\mathrm{pH}$, enolization of $\mathrm{C}_{1}$ and $\mathrm{C}_{2}$ carbon and removal of the amino group in position 1 and the carboxyl group at position 3 are favored, resulting in 1,2-dicarbonyl compounds (via 1,2E), as glyoxal and methylglyoxal, 1-desoxiglucosulosa, and 3desoxiglucosulosa, which may undergo further dehydration resulting in furfural, such as 5-(hydroxymethyl) furfural (HMF) [38].
Concerning functional properties of whey glycosylated products, in this work it is shown that conjugates from WPC and WPCH had an excellent solubility; however this value reduced notably in long heating products. Figure 4 shows functional properties of glycosylated products from whey milk in individual experiments with ribose and glucose at $50^{\circ} \mathrm{C}$ and variations of $\mathrm{pH} 7$ and $\mathrm{pH} 9$.

Emulsion property did not change with respect to value in whey, while foam property was incremented in some cases. In general, a high volume of foam was obtained in WCP and hydrolyzed with heating in $10 \mathrm{~h}$ at $\mathrm{pH} 7$.

Under these data, the best products found in these tests were those from WPC-R and WPCH-R at $\mathrm{pH} 7$ with heating for 10-15 h. Therefore, conjugates obtained could be excellent antioxidants and/or functional additives in formulated foods [39].

Current studies have shown that conjugates from sodium caseinate [40] and $\beta$-lactoglobulin [41] with galactose have the capacity to form and stabilize food emulsions. The best results were obtained in these experiments with glycated proteins at $50^{\circ} \mathrm{C}$ and $\mathrm{pH} 5$ during $48 \mathrm{~h}$ (corresponding to the latest steps of MR). This behavior can be attributed to the 


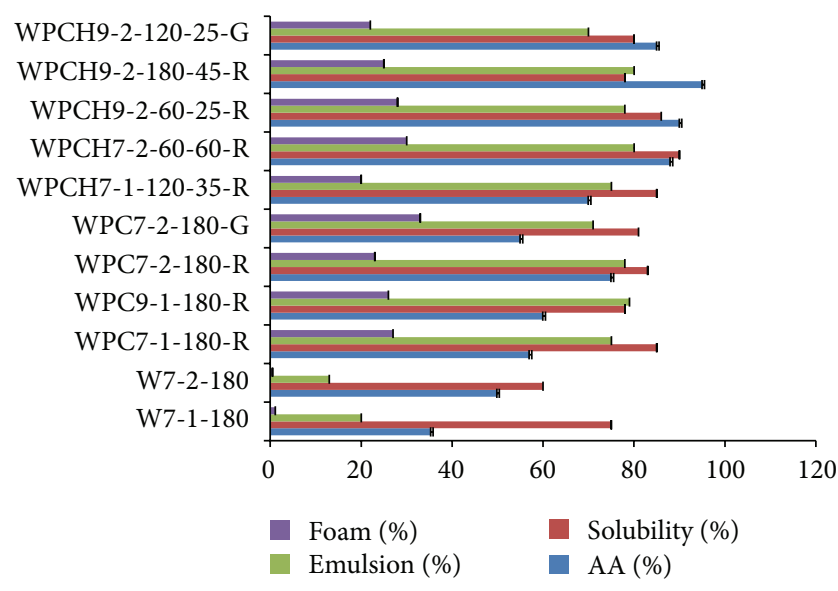

FIGURE 4: Functional properties of glycosylated products from whey milk in individual experiments with ribose and glucose at $50^{\circ} \mathrm{C}$ and variations of $\mathrm{pH} 7$ and $\mathrm{pH} 9$.

higher adsorption efficiency and degree of interfacial interaction exhibited by the glycoconjugates with this carbohydrate and the fact that alkaline $\mathrm{pH}$ reduces significantly the foam property.

\section{Conclusions}

The antioxidant activity and functional properties of sweet and acid whey products were incremented by polymerization of their proteins by glycation with heating and addition of glucose and ribose.

Glycation of whey protein concentrates (WPC) and the hydrolyzates (WPCH) with ribose and glucose showed different oxidation values.

The higher activity was found in WPC glycosylates products with ribose at $\mathrm{pH} 7$ and heating at $50^{\circ} \mathrm{C}$ during $10-15 \mathrm{~h}$. In the same way, antioxidant activity in WPCH was incremented by prior hydrolysis to glycation in products with $25-45 \%$ hydrolysis degree at $\mathrm{pH}$ 9. In these processes was found an important dependence on $\mathrm{pH}$ conditions and carbohydrate reactivity; therefore antioxidant activity was associated with carbohydrate type used in glycation of whey proteins.

Functional properties of these products (solubility, emulsion, and foam) were also maintained or improved by the glycation with ribose.

The color in glycosylates products with glucose was more intense than in products with ribose; however antioxidant activity was not associated with this change. Formation of hydroxyl groups could probably inhibit this action.

Other researchers are required to identify the structure of the compounds in the conjugates that could inhibit the capacities of conjugates with glucose. In addition, practical applications of these products are necessary to test their antioxidant capacity as additive in foods.

\section{Conflict of Interests}

The authors declare that there is no conflict of interests regarding the publication of this paper.

\section{References}

[1] J. Liu, Q. Ru, and Y. Ding, "Glycation a promising method for food protein modification: physicochemical properties and structure, a review," Food Research International, vol. 49, no. 1, pp. 170-183, 2012.

[2] C. Sun and S. Gunasekaran, "Effects of protein concentration and oil-phase volume fraction on the stability and rheology of menhaden oil-in-water emulsions stabilized by whey protein isolate with xanthan gum," Food Hydrocolloids, vol. 23, no. 1, pp. 165-174, 2009.

[3] L. M. Tong, S. Sasaki, D. J. McClements, and E. A. Decker, "Mechanisms of the antioxidant activity of a high molecular weight fraction of whey," Journal of Agricultural and Food Chemistry, vol. 48, no. 5, pp. 1473-1478, 2000.

[4] J. M. C. Gutteridge, S. K. Paterson, A. W. Segal, and B. Halliwell, "Inhibition of lipid peroxidation by the iron-binding protein lactoferrin," Biochemical Journal, vol. 199, no. 1, pp. 259-261, 1981.

[5] E. Meucci, A. Mordente, and G. E. Martorana, "Metal-catalyzed oxidation of human serum albumin: conformational and functional changes. Implications in protein aging," The Journal of Biological Chemistry, vol. 266, no. 8, pp. 4692-4699, 1991.

[6] A. Moure, H. Domínguez, and J. C. Parajó, "Antioxidant properties of ultrafiltration-recovered soy protein fractions from industrial effluents and their hydrolysates," Process Biochemistry, vol. 41, no. 2, pp. 447-456, 2006.

[7] I. Arcan and A. Yemenicioğlu, "Antioxidant activity of protein extracts from heat-treated or thermally processed chickpeas and white beans," Food Chemistry, vol. 103, no. 2, pp. 301-312, 2007.

[8] G.-N. Kim, H.-D. Jang, and C.-I. Kim, "Antioxidant capacity of caseinophosphopeptides prepared from sodium caseinate using Alcalase," Food Chemistry, vol. 104, no. 4, pp. 1359-1365, 2007.

[9] T. Bayram, M. Pekmez, N. Arda, and A. S. Yalçin, "Antioxidant activity of whey protein fractions isolated by gel exclusion chromatography and protease treatment," Talanta, vol. 75, no. 3, pp. 705-709, 2008.

[10] A. Dryáková, A. Pihlanto, P. Marnila, L. Čurda, and H. J. T. Korhonen, "Antioxidant properties of whey protein hydrolysates as measured by three methods," European Food Research and Technology, vol. 230, no. 6, pp. 865-874, 2010.

[11] C. Muro Urista, R. Álvarez Fernández, F. Riera Rodríguez, A. Arana Cuenca, and A. Téllez Jurado, "Review: production and functionality of active peptides from milk," Food Science and Technology International, vol. 17, no. 4, pp. 293-317, 2011.

[12] J. A. Gerrard, "Protein-protein crosslinking in food: methods, consequences, applications," Trends in Food Science and Technology, vol. 13, no. 12, pp. 391-399, 2002.

[13] N. Liu, T. Zhang, Y. J. Wang, Y. P. Huang, J. H. Ou, and P. Shen, "A heat inducible tyrosinase with distinct properties from Bacillus thuringiensis," Letters in Applied Microbiology, vol. 39, no. 5, pp. 407-412, 2004.

[14] G. Liu and Q. Zhong, "Thermal aggregation properties of whey protein glycated with various saccharides," Food Hydrocolloids, vol. 32, no. 1, pp. 87-96, 2013.

[15] S.-C. Liu, D.-J. Yang, S.-Y. Jin, C.-H. Hsu, and S.-L. Chen, "Kinetics of color development, $\mathrm{pH}$ decreasing, and antioxidative activity reduction of Maillard reaction in galactose/glycine model systems," Food Chemistry, vol. 108, no. 2, pp. 533-541, 2008. 
[16] M. Murakami, H. Tonouchi, R. Takahashi et al., "Structural analysis of a new anti-hypertensive peptide ( $\beta$-lactosin B) isolated from a commercial whey product," Journal of Dairy Science, vol. 87, no. 7, pp. 1967-1974, 2004.

[17] G. P. Rizzi, "Free radicals in the Maillard reaction," Food Reviews International, vol. 19, no. 4, pp. 375-395, 2003.

[18] M.-N. Maillard, C. Billaud, Y.-N. Chow, C. Ordonaud, and J. Nicolas, "Free radical scavenging, inhibition of polyphenoloxidase activity and copper chelating properties of model Maillard systems," LWT_Food Science and Technology, vol. 40, no. 8, pp. 1434-1444, 2007.

[19] F. J. Morales and M.-B. Babbel, "Antiradical efficiency of Maillard reaction mixtures in a hydrophilic media," Journal of Agricultural and Food Chemistry, vol. 50, no. 10, pp. 2788-2792, 2002.

[20] M. S. Rao, S. P. Chawla, R. Chander, and A. Sharma, "Antioxidant potential of Maillard reaction products formed by irradiation of chitosan-glucose solution," Carbohydrate Polymers, vol. 83, no. 2, pp. 714-719, 2011.

[21] J. A. Rufián-Henares and F. J. Morales, "Functional properties of melanoidins: in vitro antioxidant, antimicrobial and antihypertensive activities," Food Research International, vol. 40, no. 8, pp. 995-1002, 2007.

[22] M. Carabasa-Giribet and A. Ibarz-Ribas, "Kinetics of colour development in aqueous glucose systems at high temperatures," Journal of Food Engineering, vol. 44, no. 3, pp. 181-189, 2000.

[23] X. Tovar Jiménez, A. Arana Cuenca, A. Téllez Jurado, A. Abreu Corona, and C. R. Muro Urista, "Traditional methods for whey protein isolation and concentration: effects on nutritional properties and biological activity," Journal of the Mexican Chemical Society, vol. 56, no. 4, pp. 369-377, 2012.

[24] A. Fechner, A. Knoth, I. Scherze, and G. Muschiolik, "Stability and release properties of double-emulsions stabilised by caseinate-dextran conjugates," Food Hydrocolloids, vol. 21, no. 5-6, pp. 943-952, 2007.

[25] M. Ozgen, R. N. Reese, A. Z. Tulio Jr., J. C. Scheerens, and A. R. Miller, "Modified 2,2-azino-bis-3-ethylbenzothiazoline-6sulfonic acid (ABTS) method to measure antioxidant capacity of selected small fruits and comparison to ferric reducing antioxidant power (FRAP) and 2,2' -diphenyl-1-picrylhydrazyl (DPPH) methods," Journal of Agricultural and Food Chemistry, vol. 54, no. 4, pp. 1151-1157, 2006.

[26] C. V. Morr and E. Y. W. Ha, "Whey protein concentrates and isolates: processing and functional properties," Critical Reviews in Food Science and Nutrition, vol. 33, no. 6, pp. 431-476, 1993.

[27] K. N. Pearce and J. E. Kinsella, "Emulsifying properties of proteins: evaluation of a turbidimetric technique," Journal of Agricultural and Food Chemistry, vol. 26, no. 3, pp. 716-723, 1978.

[28] R. He, X. Ju, J. Yuan, L. Wang, A. T. Girgih, and R. E. Aluko, "Antioxidant activities of rapeseed peptides produced by solid state fermentation," Food Research International, vol. 49, no. 1, pp. 432-438, 2012.

[29] L. Zhang, J. Li, and K. Zhou, "Chelating and radical scavenging activities of soy protein hydrolysates prepared from microbial proteases and their effect on meat lipid peroxidation," Bioresource Technology, vol. 101, no. 7, pp. 2084-2089, 2010.

[30] S. B. Kim, H. S. Shin, and J. W. Lim, "Separation of calciumbinding protein derived from enzymatic hydrolysates of cheese whey protein," Asian Australasian Journal of Animal Sciences, vol. 17, no. 5, pp. 712-718, 2004.
[31] W.-Q. Wang, Y.-H. Bao, and Y. Chen, "Characteristics and antioxidant activity of water-soluble Maillard reaction products from interactions in a whey protein isolate and sugars system," Food Chemistry, vol. 139, no. 1-4, pp. 355-361, 2013.

[32] X. Q. Huang, Z. C. Tu, H. Xiao et al., "Characteristics and antioxidant activities of ovalbumin glycated with different saccharides under heat moisture treatment," Food Research International, vol. 48, no. 2, pp. 866-872, 2012.

[33] Q. Liu, B. Kong, J. Han, C. Sun, and P. Li, "Structure and antioxidant activity of whey protein isolate conjugated with glucose via the Maillard reaction under dry-heating conditions," Food Structure, vol. 1, no. 2, pp. 145-154, 2014.

[34] M. Daglia, A. Papetti, C. Aceti, B. Sordelli, C. Gregotti, and G. Gazzani, "Isolation of high molecular weight components and contribution to the protective activity of coffee against lipid peroxidation in a rat liver microsome system," Journal of Agricultural and Food Chemistry, vol. 56, no. 24, pp. 1165311660, 2008.

[35] M. S. Rao, S. P. Chawla, R. Chander, and A. Sharma, "Antioxidant potential of Maillard reaction products formed by irradiation of chitosan-glucose solution," Carbohydrate Polymers, vol. 83, no. 2, pp. 714-719, 2011.

[36] C. M. Oliver, L. D. Melton, and R. A. Stanley, "Functional properties of caseinate glycoconjugates prepared by controlled heating in the 'dry' state," Journal of the Science of Food and Agriculture, vol. 86, no. 5, pp. 732-740, 2006.

[37] J. Buchert, D. E. Cura, H. Ma et al., "Crosslinking food proteins for improved functionality," The Annual Review of Food Science and Technology, vol. 1, no. 1, pp. 113-138, 2010.

[38] Y. Sun, S. Hayakawa, M. Chuamanochan, M. Fujimoto, A. Innun, and K. Izumori, "Antioxidant effects of Maillard reaction products obtained from ovalbumin and different Daldohexoses," Bioscience, Biotechnology and Biochemistry, vol. 70, no. 3, pp. 598-605, 2006.

[39] F. Nacka, J.-M. Chobert, T. Burova, J. Léonil, and T. Haertlé, "Induction of new physicochemical and functional properties by the glycosylation of whey proteins," Journal of Protein Chemistry, vol. 17, no. 5, pp. 495-503, 1998.

[40] M. Corzo-Martínez, C. Carrera-Sánchez, M. Villamiel, J. M. Rodríguez-Patino, and F. J. Moreno, "Assessment of interfacial and foaming properties of bovine sodium caseinate glycated with galactose," Journal of Food Engineering, vol. 113, no. 3, pp. 461-470, 2012.

[41] M. Corzo-Martínez, C. Carrera Sánchez, F. J. Moreno, J. M. Rodríguez Patino, and M. Villamiel, "Interfacial and foaming properties of bovine $\beta$-lactoglobulin: galactose Maillard conjugates," Food Hydrocolloids, vol. 27, no. 2, pp. 438-447, 2012. 

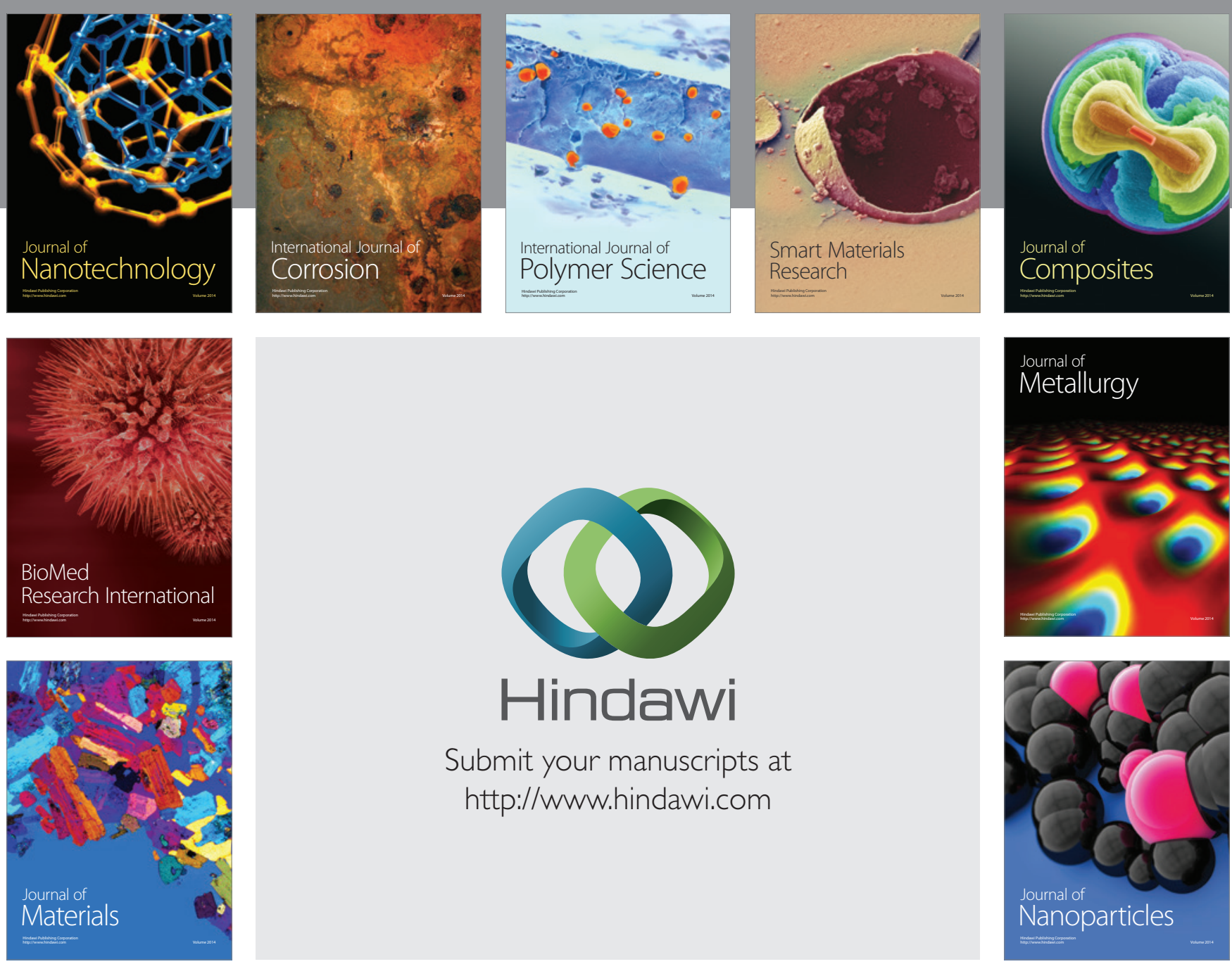

Submit your manuscripts at http://www.hindawi.com
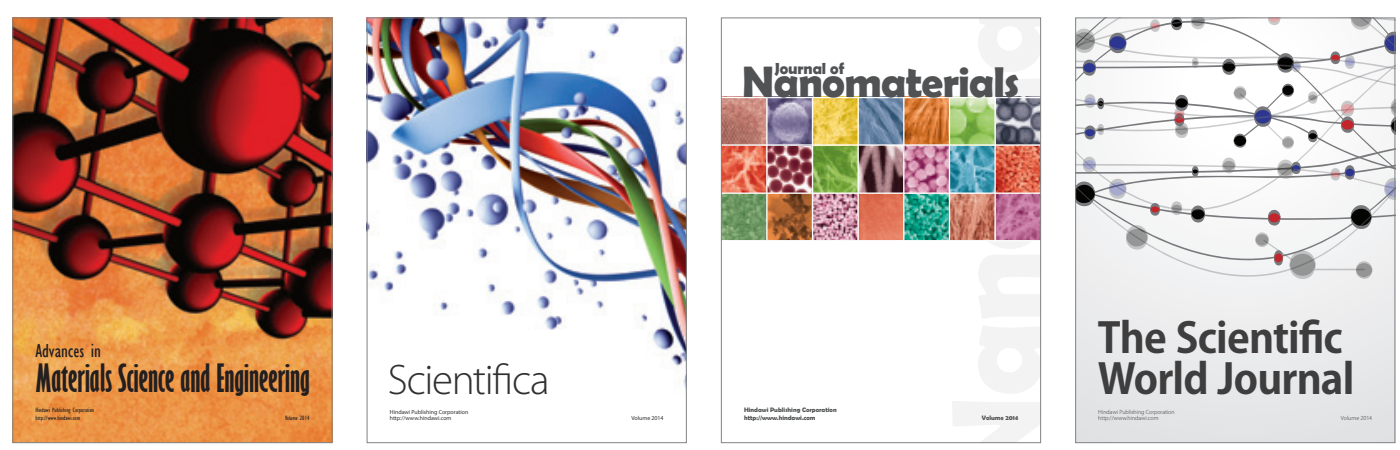

\section{The Scientific World Journal}
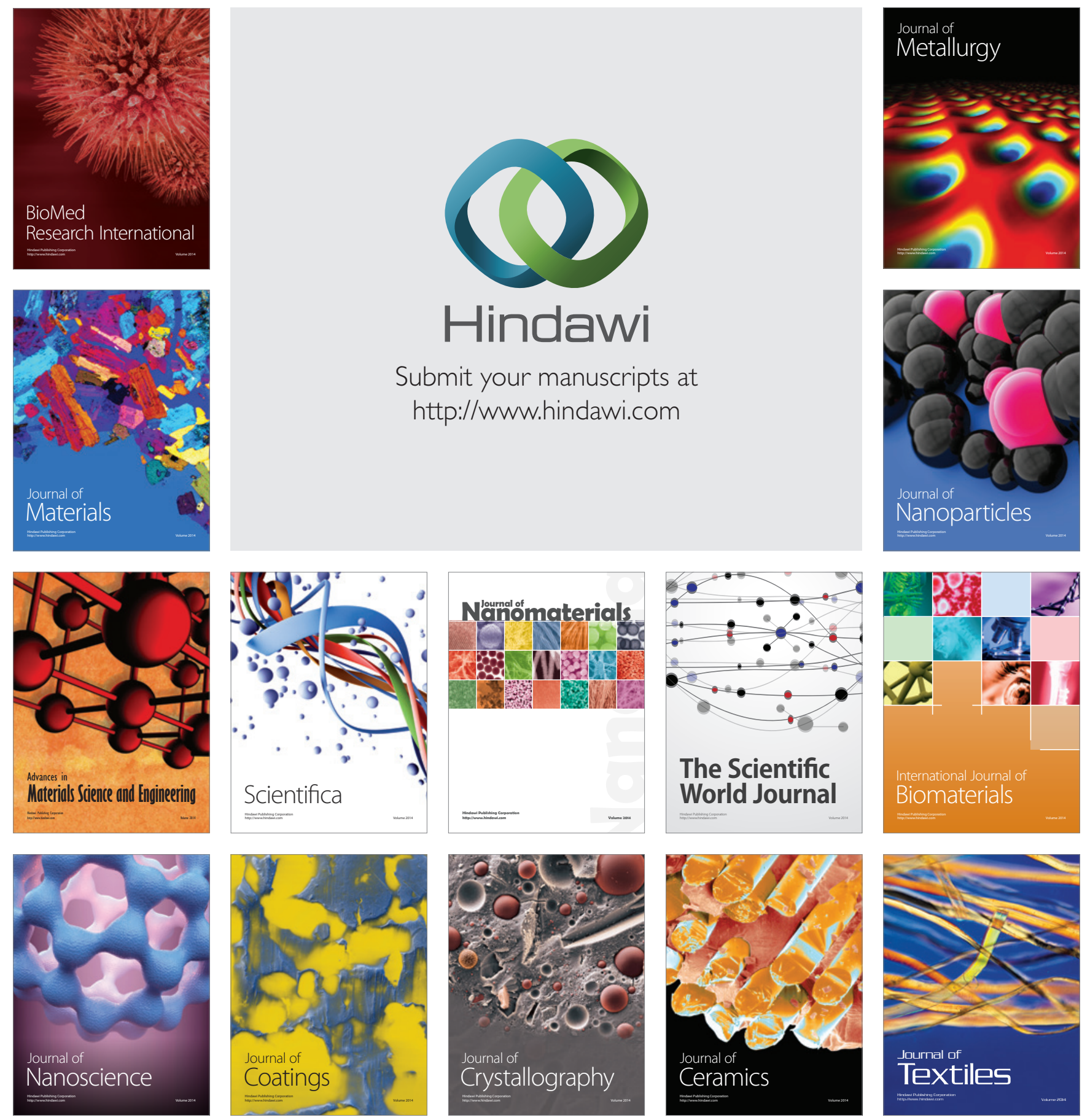